\title{
Rice Farming in Central Java, Indonesia-Adoption of Sustainable Farming Practices, Impacts and Implications
}

\author{
Melanie Connor ${ }^{1, *(D)}$, Annalyn H. de Guia ${ }^{1} \mathbb{D}$, Arlyna Budi Pustika ${ }^{2}$, Sudarmaji ${ }^{2}$, Mahargono Kobarsih ${ }^{2}$ and \\ Jon Hellin ${ }^{1}$ (D) \\ 1 International Rice Research Institute (IRRI), DAPO Box 7777, Metro Manila 1301, Philippines; \\ a.deguia@irri.org (A.H.d.G.); j.hellin@irri.org (J.H.) \\ 2 Yogyakarta Assessment Institute of Agricultural Technology, JI Stadion Maguwoharjo No 22 Ngemplak \\ Sleman, Yogyakarta, Indonesia; arlynabudi@gmail.com (A.B.P.); sudarmaji2@yahoo.com (S.); \\ mahargonojogja@gmail.com (M.K.) \\ * Correspondence: m.connor@irri.org
}

\section{check for} updates

Citation: Connor, M.; de Guia, A.H.; Pustika, A.B.; Sudarmaji; Kobarsih, M.; Hellin, J. Rice Farming in Central Java, Indonesia-Adoption of Sustainable Farming Practices, Impacts and Implications. Agronomy 2021, 11, 881. https://doi.org/ 10.3390/agronomy11050881

Academic Editors: Marta Monjardino, Geoff Kuehne and Khondoker Abdul Mottaleb

Received: 24 March 2021 Accepted: 28 April 2021 Published: 29 April 2021

Publisher's Note: MDPI stays neutral with regard to jurisdictional claims in published maps and institutional affiliations.

Copyright: (c) 2021 by the authors. Licensee MDPI, Basel, Switzerland. This article is an open access article distributed under the terms and conditions of the Creative Commons Attribution (CC BY) license (https:// creativecommons.org/licenses/by/ $4.0 /)$.

\begin{abstract}
Farmer adoption of sustainable rice farming technologies and practices is critical for climate change adaptation and mitigation. Often adoption is investigated in isolation focusing on factors influencing farmer decision making and overlooking the effects of technology adoption on farmers' livelihoods and perceptions of change. Therefore, the present study investigated technology adoption and its effects on farmers with a special focus on additional revenue allocation and perception of social, economic and environmental change. Using a digital survey platform, 153 farmers ( $21.6 \%$ female) were interviewed in three sub-districts of Yogyakarta, Indonesia. On average, farmers adopted two technologies or practices, adopted high-yielding rice varieties, and increased their revenue from US $\$ 105$ to US\$122 per hectare per season. Barriers to adoption included time constraints, unsuitability for field conditions and incompatibility with cropping systems. Farmers invested the extra income in farming business and improved diets. Furthermore, farmers perceived changes in social and human capital and also poverty reduction due to technology adoption. This study highlights the importance of including an analysis of social impact in agricultural research.
\end{abstract}

Keywords: farmer adoption; impact; income allocation; adoption constraints

\section{Introduction}

The Global South is prone to extreme climate events such as droughts, high temperatures, erratic rainfall and floods that threaten sustainable agricultural development. Smallholder farmers are among the most vulnerable people affected by extreme climate events. In response, a suite of agricultural technologies and practices, known collectively as climate-smart agriculture (CSA), has been developed and promoted. CSA has three objectives: (i) increase agricultural productivity to support food security and broader development goals; (ii) increase adaptive capacity and resilience to climate variability and (iii) decrease greenhouse gas emissions [1]. CSA includes, among others, climate-adapted crop varieties and improved land management practices. CSA is critical to agricultural development and realization of several Sustainable Development Goals (SDGs). Numerous climate change mitigation and adaptation initiatives worldwide encourage farmer adoption of CSA $[2,3]$.

Indonesia, an archipelago consisting of 17,504 islands [4], is the world's third largest rice producer and being the world's fourth most populous country it is also one of the world's main rice consumers [5]. Rice is the most important food crop with an annual production of 81 million tons of dry unhusked rice [6]. In 2018, rice fields accounted for 8 million ha of land with more than half of this land being irrigated rice land [7]. Rice is grown across the major islands of Indonesia but most rice is cultivated on the island of Java on an estimated 3.1 million ha of land [7]. Indonesia has extensive coastal agro-ecological 
zones that are highly vulnerable to the effects of climate change [8]. CSA is of particular interest to smallholder farmers in Indonesia who manage a plethora of climate-related risks, including droughts, flooding, and changing monsoonal activities [9]. Such phenomena have adverse effects on the size of rice cultivation areas, delay planting times, and decrease rice yields [9]. Smallholder rice farmers in Jakenan, Central Java use climate forecasts in decision making especially to determine planting time and select crop varieties [9]. The combination of saline-tolerant rice varieties and improved nutrient management use is a good strategy for improving farmers' livelihoods while promoting sustainable rice production [10]. In the riparian wetlands of South Sumatra intensive observation of farmer's practices and dialogues with farmers about their constraints intensifying food production have revealed needs, preferences, and absorptive capacity of smallholder rice farmers [11].

The Special Region of Yogyakarta is situated in southern Java bordering the Indian Ocean. On Java, approximately $29 \%$ of the rice-growing areas are within $10 \mathrm{~km}$ of the coast [10]. In recent years the productivity of paddy fields has decreased particularly during the dry season [4]. In response, development projects have promoted CSA. CSA practices were introduced to Yogyakarta as early as 2012 through the Closing Rice Yield Gaps in Asia (CORIGAP) project funded by the Swiss Agency for Development and Cooperation (SDC). Improved rice varieties, alternate wetting and drying (AWD), drum seeders, mechanical transplanters, combine harvesters, and superbags for storage were introduced over a timeframe of four years via adaptive participatory processes (Table 1).

Table 1. Technologies and practices introduced by the CORIGAP projects, explanation of the technology and practices, and CSA aspects.

\begin{tabular}{|c|c|c|}
\hline Technology or Practice & Explanation & CSA Aspects \\
\hline Improved varieties & $\begin{array}{l}\text { High-yielding rice varieties Ciheang and } \\
\text { Inpari 6-30 were introduced }\end{array}$ & $\begin{array}{l}\text { Quality seeds and planting materials, } \\
\text { well adapted, high-yielding varieties [12] }\end{array}$ \\
\hline Alternate wetting and drying (AWD & $\begin{array}{l}\text { The field is not continuously flooded, the } \\
\text { soil is allowed to dry out for one or } \\
\text { several days after the disappearance of } \\
\text { ponded water before it is flooded } \\
\text { again [13]. }\end{array}$ & $\begin{array}{c}\text { Water management technique, mitigating } \\
\text { greenhouse gas emissions from rice } \\
\text { production [14] }\end{array}$ \\
\hline Drum seeder & $\begin{array}{l}\text { Plants rice seeds, preferably } \\
\text { pre-germinated, directly in neat rows }\end{array}$ & $\begin{array}{l}\text { Sustainable mechanization, efficient } \\
\text { cropping process }\end{array}$ \\
\hline Mechanical transplanter & Mechanical transplanting machine & $\begin{array}{l}\text { Transplanting rice reduces fuel, labor } \\
\text { costs, and water requirements, } \\
\text { sustainable mechanization with direct } \\
\text { and indirect reduction in greenhouse } \\
\text { gases }\end{array}$ \\
\hline Combine harvester & Mechanical harvest & $\begin{array}{l}\text { Reduce post-harvest losses, sustainable } \\
\text { mechanization, timely availability of } \\
\text { equipment allows for cropping process to } \\
\text { be efficient, direct and indirect reduction } \\
\text { in greenhouse gases [12] }\end{array}$ \\
\hline Superbag & $\begin{array}{l}\text { Hermetic storage bag for cereal grains to } \\
\text { be stored safely for extended periods }\end{array}$ & $\begin{array}{l}\text { Extends the germination life of seeds } \\
\text { from } 6 \text { to } 12 \text { months, controls insect grain } \\
\text { pests without chemicals, improves head } \\
\text { rice recovery, and, therefore, provide } \\
\text { quality seeds a part of CSA [12] }\end{array}$ \\
\hline
\end{tabular}

Persuading farmers to try out and consequently adopt new practices is challenging. Adoption rates of CSA practices in Indonesia are low [11]. Increasingly, agricultural extension agents serve as intermediaries to enhance communication between technology developers and farmers $[15,16]$. The CORIGAP project recognized that single, isolated 
interventions are unlikely to be sufficient for sustainable, climate-friendly rice production and, therefore, promoted a variety of sustainable practices and technologies (Table 1). An adaptive, participatory diffusion process can more readily factor in the heterogeneity of farmers' needs and support priority setting at the local level compared to the more common top-down approach [17]. CORIGAP thus periodically organized demonstration sites, farmer field schools, and trainings.

There is a plethora of research investigating the uptake of agricultural practices in different contexts and geographies. A variety of external factors such as farmers' field conditions [18], e.g., soil texture [19], access to electric power [19] and irrigation [18], membership of farmer groups [20] and accessibility to agricultural extension services [21] have been shown to determine farmers adoption of new technologies and practices. Furthermore, internal or personal factors such as knowledge and belief in climate change [22], farmer motivation [23], and farmers' perception of ease of implementation [18] have also been shown to influence the adoption of CSA and other sustainable agricultural practices. Relatively few adoption studies address the critical issue of the impacts of farmer adoption i.e., whether farmer adoption is contributing to change, and whether change is beneficial or, even in some cases, detrimental e.g., maladaptation [24-26]. The present study, therefore, extends previous research in Southeast Asia investigating the adoption of sustainable farming practices in Vietnam [18] and documenting the impact of adoption the Myanmar $[27,28]$ by evaluating the effects of adoption on farmers' lives. We investigated the uptake of CSA practices and technologies that CORIGAP promoted in Yogyakarta. We analyzed a three-step process: awareness, trial and adoption based on Lambrecht et al. (2014) [29]. Furthermore, we investigated contribution of farmer adoption to social, economic and environmental change. Such understanding is critical in order to determine whether extant theories of change reflect actual processes linking research outputs to outcomes and impacts, or whether changes in project design and implementation are required in order to generate greater impact. The Indonesia study is an example of the evolution of climate-resilient farming systems.

\section{Materials and Methods}

\subsection{Questionnaire Development}

A survey questionnaire was created to investigate the adoption of sustainable rice farming practices. The development of the questionnaire was based on similar studies conducted under the auspices of CORIGAP in Vietnam [18] and China [30] and adapted to the Indonesian context. The survey questionnaire was pre-tested with the Indonesian partner organization and sample farmers during training activities. The questionnaire started with a consent form informing the participants about the purpose of this study. Furthermore, participants were informed that their participation was voluntary, that no personal information other than gender, age, and education was going to be collected, and that participants were free to stop the survey at any time without penalty. The questionnaire was divided into six main parts and started with farmer demographic information and technology details. Farmers were asked which technologies introduced by CORIGAP they had used, when they started using them and whether they were still using them. When farmers had abandoned technologies and practices, follow up questions explored the reasons behind this. Eighteen possible reasons for discontinuation were evaluated on a 6-point Likert type scale $(1=$ not applicable at all, $6=$ very applicable) $[18,30]$.

The next three parts concerned agronomic and economic data from the different cropping seasons-dry season 2017, wet season 2017/2018, and wet season 2018. For each season that the respondents planted rice, they were asked about farm-related details in terms of farm size (in hectare) designated for rice and other crops (as in sequential cropping), status of land tenure whether owned or leased, and the cost of the lease. They were also asked about total rice production from the land they cultivate using the suite of technologies. To derive the production costs, questions were provided regarding the in-kind and cash payments on seeds, fertilizers, pesticides and other pest control methods, 
payment for irrigation, hauling costs, hired labor, and machine rental for land preparation, planting, and harvesting. A production distribution section was also provided portioning all forms of paddy (fresh, dry, seed stock, for milling) volume that is for sale, consumption, and storage. Selling prices (in Indonesian Rupiah/kilogram) of each product form were also gathered.

Farmers were also asked what percentage of their rice and non-rice income they used for expenditure such as food, clothing, mobile phones, and for investments in farming and housing. Participants allocated their income to 20 different items (including food, rice production inputs, transport, clothing, and home improvements). Participants were asked whether they thought they had increased their income from rice due to the use of the CORIGAP technologies. Farmers who reported an increase in income were further asked to estimate the increase and how they had spent the additional income. Only farmers who could remember how they spent the additional income were asked about the percentage of income allocated to the same 20 items. The last part concerned farmers' perceptions of changes since the introduction of the sustainable farming practices. The dimensions of change are based on Wehmeyer et al. (2020) [30]. In total, twelve dimensions of change were evaluated-economic, social and environmental changes included financial capital, employment, physical capital, social capital, human capital, natural capital, food security, cultural capital and health [30]. Each dimension of change was assessed on a number of items (full list of items can be found in Tables S1 and S2). All items were measured on a 6-point Likert-type scale ranging from $1=$ completely disagree to $6=$ fully agree.

All questionnaires were conceptualized in English and translated into Bahasa Indonesia. To ensure content and context validity, the questionnaire was back translated by an independent third translator. The questionnaire was built online on the CommCare HQ dashboard (CommCare version 2.44.3, Dimagi, Cambridge, MA, USA) and was disseminated through face-to-face interviews using the mobile data collection application CommCare which was installed on Samsung Galaxy Tablets A7.0 (2016) LTE SM-T285 (Samsung, Seoul, Korea).

\subsection{Sampling}

All respondents belong to a local government's list of farmers participating in CORIGAP and, hence, exposed to sustainable farming practices. The total list contained 180 farmers who were randomly selected for the project. From this list, all farmers who have at least adopted one technology or practice were eligible to take part in the present study. In total, 153 had adopted one or more technologies and all of these farmers were eligible to participate and, therefore, purposively sampled. Farmers either participated in capacity building activities or were direct recipients of farm equipment and machinery to trial in their fields. Geographic units (i.e., sub-district, village, and commune) were selected to minimize travel time and maximize number of farmers to be interviewed in the same location or close by locations on the same day. All 153 farmers were interviewed. Farmers were reached via phone or were visited to invite them formally as a form of courtesy to participate in the survey. A central survey location was arranged in each commune or village to enable farmers to gather for the interview. The enumerators composed eleven researchers and extension officers from Yogyakarta Assessment Institute for Agricultural Technology (locally known as BPTP-Yogyakarta). They received prior training on how to use the app-based questionnaire as well as how to deliver a digital survey to farmers. The survey was conducted in the Special Region of Yogyakarta covering the three sub-districts of Prambanan, Piyungan, and Berbah (Figure 1). Data were collected from 10 to 14 September 2018 and took approximately 30 to $45 \mathrm{~min}$ to complete. Participating farmers received a reimbursement of their travel costs and a meal. 


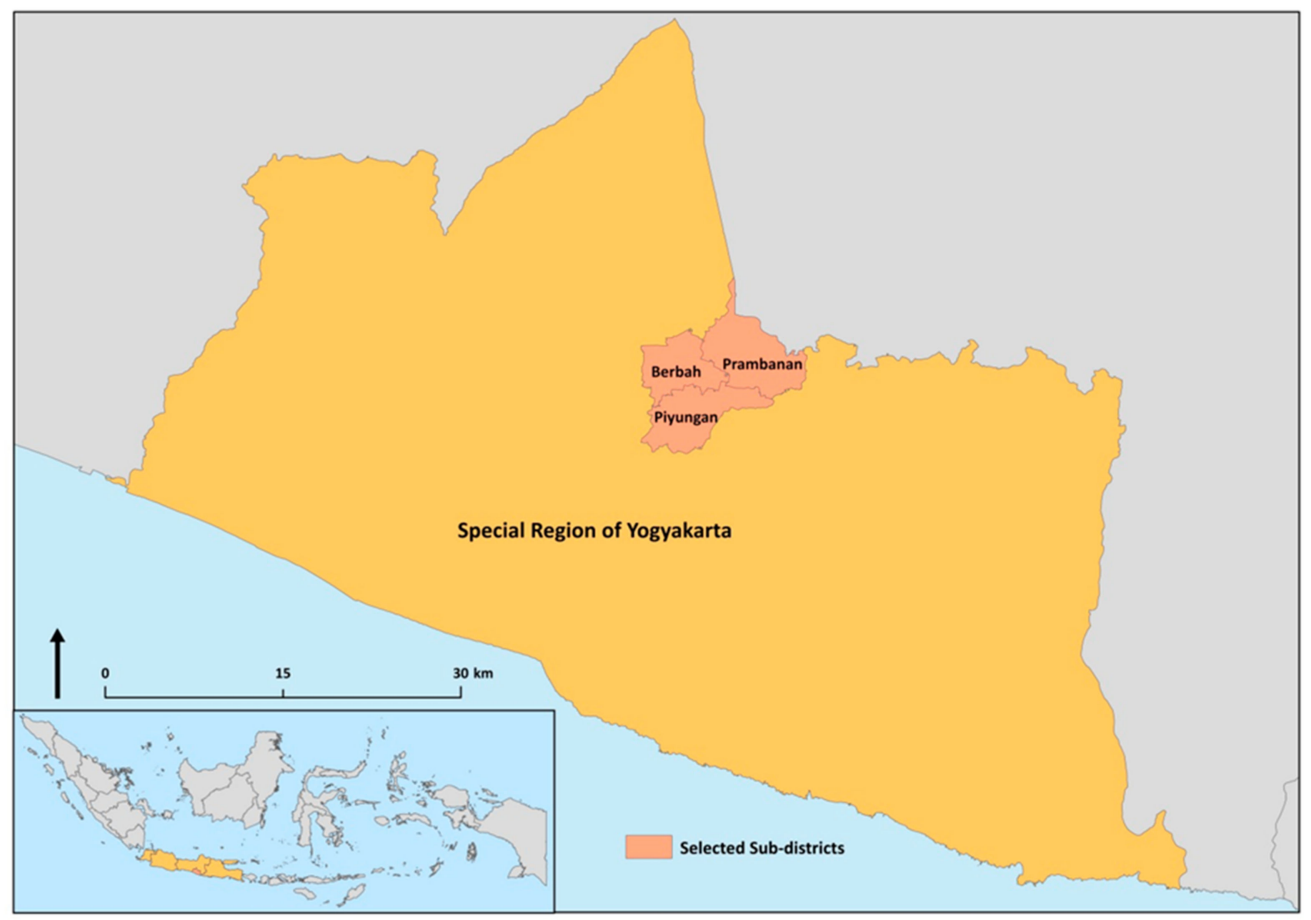

Figure 1. Study location in the Special Region of Yogyakarta Concept: M. Connor, Cartography: H. Wehmeyer, Cartographic base: Database of Global Administrative Areas (GADM). Download GADM Data (Version 3.6)—Country: Indonesia.

\subsection{Data Analysis}

Raw data were stored on the CommCare dashboard and exported into Excel (version 2001, Microsoft, Redmond, WA, USA). The different data forms were merged by a unique farmer ID and subsequently imported into the statistical software package SPSS (version 27, IBM, Armonk, NY, USA) and Stata (version 14, StataCorp, College Station, TX, USA). For the statistical analysis, local units were used but for the presentation of the results they were converted into USD (US\$1 = IDR 14,891.82). Descriptive statistics were used to provide information about the sample, the technologies and practices used, and socioeconomic, financial, and agronomic data. Agricultural performance was analyzed by producing total production quantities $(t)$, yield $(t / h a)$, and agricultural inputs (USD/ha) to calculate the estimated average gross and net income (USD/ha). In addition, a partial budget analysis was conducted to investigate changes in profitability.

Profitability analysis showed the combined net profit from rice farming for the three seasons. The computed profit is the difference between total revenue and all associated cash costs of production. We only captured the explicit values (cash operating costs and revenue) of rice production and did not include the economic and opportunity costs of capital, family labor, and land tenure. The factors for the profitability analysis in the 2017/2018 cropping year were used as base values for the partial budgeting analysis in order to retrospect the farm changes that took place (i.e., changes in area cultivated, yield, and input costs) and to estimate how much the farmers could have been spending or earning before technology introduction. Partial budgeting was also included to derive the net change in profit that can be attributed to changes in rice farming practices. We initially estimated the farmer's total additional costs and reduced revenue, and then estimated the total additional revenue and reduced costs experienced through adopting new technologies and best management practices. In other words, the partial budget refers back to what could have been the costs and earnings in the past before the introduction of CSA.

For each latent construct reflecting a dimension of change a Cronbach's $\alpha$ was computed to provide a measure for internal consistency. Mean scores were computed using the average scoring of the number of items measuring the latent construct. 


\section{Results}

\subsection{Sample Description}

In total, 153 farmers participated in this study. Most farmers were male $(n=120$, $78.4 \%)$ and $21.3 \%(n=33)$ were female. On average, participants were 57.6 years old $(\mathrm{SD}=11$ years, $\min =32, \max =83)$. The average household size was $3.6(\mathrm{SD}=1.5)$. Furthermore, participants had been farming for an average of 31.4 years ( $\mathrm{SD}=16$ years). However, most farmers $(n=102,66.7 \%)$ had an additional non-rice income, defined as any type of income other than from rice; on average, this accounts for up to $59.5 \%$ ( $\mathrm{SD}=21.4$ ) of total income.

\subsection{Farm Characteristics}

Farmers in general followed three cropping schedules: dry season planting (DS, 2017), first wet season planting (WS1, 2017/2018) and a second wet season planting (WS2, 2018). The first wet season was from November 2017 to March 2018, and the second wet season from March to July 2018. Only $29 \%(n=44)$ of the farmers planted rice in the dry season but $95 \%(n=145)$ in the first wet season and $89 \%(n=133)$ in the second wet season. Farmers in Yogyakarta have relatively small land holdings, and the area cultivated for rice in DS, WS1, and WS2 are on average $1400 \mathrm{~m}^{2}(\mathrm{SD}=1000), 1300 \mathrm{~m}^{2}(\mathrm{SD}=900)$, and $1200 \mathrm{~m}^{2}$ $(\mathrm{SD}=700)$, respectively. Farmers' average yield in the dry season is 5.9 tons $/$ ha $(\mathrm{SD}=2.3)$ of fresh paddy while in the WS1 and WS2 it was 5.8 tons/ha $(\mathrm{SD}=1.9)$ and 5.7 tons/ha $(\mathrm{SD}=1.7)$, respectively. Given the current selling prices (farm gate price) at the time of the survey ranging from $\$ 0.31$ to $\$ 0.32$ per kilogram of fresh paddy (1 US $\$=$ IDR $14,891.82$ ), gross production is valued at $\$ 1900 / \mathrm{ha}(\mathrm{SD}=727)$ in the $\mathrm{DS}$, and $\$ 1855 / \mathrm{ha}(\mathrm{SD}=618)$ and $\$ 1779 /$ ha (SD = 537) in WS1 and WS2, respectively.

Input costs covered in this study are mostly of operating expense items such as seeds, fertilizers, pesticides and herbicides, irrigation fee, hired labor, and machine rental fees for hauling, land preparation, and planting. This study did not include opportunity costs such as family labor, rent, and depreciation. The total production costs in the DS averaged $\$ 467 /$ ha $(S D=229)$, while $\$ 440 /$ ha $(S D=192)$ and $\$ 448 /$ ha $(S D=193)$ in WS1 and WS2, respectively. Taking the difference between gross product value and total operating expenses, farmers' net profit in the DS amounts to an average of $\$ 1,433 /$ ha $(\mathrm{SD}=656)$. Farers perception of income change also resulted in the majority of farmers $(n=103,67 \%)$ perceiving a positive change. The average net profits in WS1 and WS2 are $\$ 1415 /$ ha $(S D=570)$ and $\$ 1331 /$ ha $(S D=523)$, respectively (Table 2).

\subsection{Technology Adoption}

In 2018, on average, farmers used two (SD = 1.57) of the introduced innovations. All farmers reported that they have been introduced to improved varieties (Table 3). A total of $97 \%$ reported that they adopted a new variety and in $2018,90 \%$ of the interviewed farmers still used the new improved variety. Farmers who stopped using a new variety expressed that the variety was replaced by another variety. Additional reasons to stop using the new varieties were low yield and the variety did not fit farmers' cropping pattern (Table 4). Farmers were also introduced to alternate wetting and drying (AWD) (23.5\%), combine harvesters $(22.2 \%)$ mechanical transplanter $(21.6 \%)$, drum seeders $(17 \%)$, and the IRRI superbag $(8.5 \%)$. 
Table 2. Profitability of rice production in Yogyakarta Indonesia with BMP technologies, 2018.

\begin{tabular}{|c|c|c|c|c|c|c|}
\hline \multirow{2}{*}{ Parameters } & \multicolumn{2}{|c|}{ Dry Season $2017(n=44)$} & \multicolumn{2}{|c|}{ Wet Season 2017/2018 $(n=145)$} & \multicolumn{2}{|c|}{ Wet Season $2018(n=133)$} \\
\hline & Mean & SD & Mean & SD & Mean & SD \\
\hline Area cultivated for rice (ha) & 0.14 & 0.10 & 0.13 & 0.09 & 0.12 & 0.07 \\
\hline Seed rate $(\mathrm{kg} / \mathrm{ha})$ & 51.36 & 30.77 & 49.32 & 23.09 & 104.06 & 121.16 \\
\hline \multicolumn{7}{|l|}{ Revenue } \\
\hline (1) Yield (kg/ha) & 5937.01 & 2271.31 & 5796.82 & 1931.27 & 5738.02 & 1732.83 \\
\hline $\begin{array}{l}\text { (2) Farm gate price } \\
(\mathrm{USD} / \mathrm{kg})\end{array}$ & 0.32 & 0.04 & 0.32 & 0.07 & 0.31 & 0.04 \\
\hline $\begin{array}{l}\text { (3) Value of production } \\
\text { (USD/ha) }\left(1^{*} 2\right)\end{array}$ & 1899.84 & 726.82 & 1854.98 & 618.01 & 1778.79 & 537.18 \\
\hline \multicolumn{7}{|l|}{ Production Cost } \\
\hline Seeds (USD/ha) & 38.58 & 24.44 & 41.58 & 39.82 & 43.27 & 54.73 \\
\hline Fertilizer (USD/ha) & 135.05 & 90.41 & 120.07 & 62.75 & 121.82 & 56.40 \\
\hline Pest control (USD/ha) & 29.97 & 31.23 & 24.02 & 15.54 & 21.39 & 12.68 \\
\hline Herbicide & 27.88 & 19.90 & 16.43 & 11.41 & 12.49 & 7.51 \\
\hline Irrigation (USD/ha) & 44.99 & 18.74 & 11.26 & 9.50 & 68.16 & 113.41 \\
\hline \multicolumn{7}{|l|}{ Machine rental cost } \\
\hline Hauling and transportation & 12.09 & - & 30.44 & 31.79 & 30.44 & 31.79 \\
\hline Land preparation & 104.16 & 34.11 & 106.16 & 37.48 & 106.61 & 38.48 \\
\hline Planting & 104.82 & 24.18 & 121.45 & 34.42 & 119.04 & 36.41 \\
\hline Harvesting & 238.93 & 127.43 & 232.53 & 143.16 & 211.63 & 46.79 \\
\hline \multirow{3}{*}{$\begin{array}{c}\text { Hired labor } \\
\text { (4) Total production cost } \\
\text { (USD/ha) } \\
\text { (5) Net profit }(3-4)\end{array}$} & 185.21 & 133.72 & 174.44 & 141.16 & 175.91 & 139.83 \\
\hline & 466.76 & 228.86 & 440.45 & 192.23 & 447.67 & 192.87 \\
\hline & 1433.08 & 655.87 & 1414.53 & 570.25 & 1331.11 & 523.41 \\
\hline \multirow{2}{*}{ Change Parameters } & \multicolumn{2}{|c|}{ Dry Season } & \multicolumn{2}{|c|}{ Wet Season 1} & \multicolumn{2}{|c|}{ Wet Season 2} \\
\hline & Mean & SD & Mean & SD & Mean & SD \\
\hline Yield pre-adoption (kg/ha) & 5607.20 & 2402.51 & 5401.82 & 1958.50 & 5347.39 & 1723.39 \\
\hline Yield change $(\mathrm{kg} / \mathrm{ha})$ & 329.80 & 545.01 & 368.71 & 666.85 & 390.63 & 901.49 \\
\hline Reduced cost (USD/ha) & - & - & 56.72 & 63.12 & 37.26 & 39.70 \\
\hline Added revenue (USD/ha) & 105.54 & 174.40 & 117.99 & 213.39 & 121.10 & 279.46 \\
\hline Net added income (USD/ha) & 105.54 & 174.40 & 121.07 & 213.47 & 122.22 & 279.50 \\
\hline
\end{tabular}

Table 3. Distribution of farmers technology utilization and adoption details, Yogyakarta Indonesia.

\begin{tabular}{|c|c|c|c|c|c|c|c|}
\hline \multirow[b]{2}{*}{ Technology } & \multicolumn{3}{|c|}{ Utilization $(n)$} & \multicolumn{2}{|c|}{ Uptake (Year) } & \multicolumn{2}{|c|}{$\begin{array}{c}\text { Length of Adoption } \\
\text { (Years) }\end{array}$} \\
\hline & $\begin{array}{c}\text { Farmers } \\
\text { Introduced }\end{array}$ & Adopted & $\begin{array}{c}\text { Still } \\
\text { Practicing } \\
\text { in } 2018\end{array}$ & Mean & SD & Mean & SD \\
\hline $\begin{array}{c}\text { Alternate wetting and } \\
\text { drying }\end{array}$ & 36 & 29 & 16 & 0.6 & 1.2 & 2.8 & 1.8 \\
\hline Solar bubble dryer & 2 & 0 & 0 & na & na & na & na \\
\hline Combine harvester & 34 & 18 & 4 & 0.2 & 0.7 & 1.4 & 1.2 \\
\hline Drum seeder & 26 & 14 & 1 & 0.1 & 0.4 & 1.4 & 1.2 \\
\hline Ecologically Based & & & & & & & \\
\hline $\begin{array}{c}\text { Rodent Management } \\
\text { (EBRM) }\end{array}$ & 4 & 3 & 2 & 0.0 & 0.0 & 5.3 & 3.8 \\
\hline Improved variety & 153 & 148 & 138 & 1.7 & 4.7 & 7.8 & 9.0 \\
\hline Mechanical transplanter & 33 & 17 & 0 & 0.2 & 0.4 & 0.9 & 0.9 \\
\hline Strip harvester & 4 & 1 & 0 & 0.0 & - & 1.0 & - \\
\hline IRRI superbag & 13 & 6 & 1 & 0.0 & - & 1.5 & 1.8 \\
\hline
\end{tabular}

Note: Uptake (year) —average year of technology uptake from introduction to adoption; length of adoption (year)—average year of using the technology from year of adoption to end of use (for those who stopped adopting) and until 2018 (year of survey); na-not applicable. 
Table 4. Farmers' Likert-scale rating on reasons to discontinue use of BMP technology, Yogyakarta Indonesia.

\begin{tabular}{|c|c|c|c|c|c|c|c|c|c|c|c|c|}
\hline \multirow{2}{*}{$\begin{array}{c}\text { Reason to } \\
\text { Discontinue Use }\end{array}$} & \multicolumn{2}{|c|}{$\begin{array}{c}\text { Improved } \\
\text { Variety }(n=10)\end{array}$} & \multicolumn{2}{|c|}{$\begin{array}{c}\text { Alternate Wetting } \\
\text { and Drying }(n=13)\end{array}$} & \multicolumn{2}{|c|}{$\begin{array}{c}\text { Combine } \\
\text { Harvester }(n=14)\end{array}$} & \multicolumn{2}{|c|}{$\begin{array}{c}\text { Drum } \\
\text { Seeder }(n=13)\end{array}$} & \multicolumn{2}{|c|}{$\begin{array}{c}\text { Mechanical } \\
\text { Transplanter }(n=17)\end{array}$} & \multicolumn{2}{|c|}{$\begin{array}{c}\text { IRRI } \\
\text { Superbag }(n=5)\end{array}$} \\
\hline & Mean & SD & Mean & SD & Mean & SD & Mean & SD & Mean & SD & Mean & SD \\
\hline Low yield & 3.80 & 1.48 & 2.46 & 1.56 & 2.07 & 1.07 & 3.23 & 1.74 & 2.59 & 1.23 & 3.60 & 1.95 \\
\hline $\begin{array}{l}\text { Does not fit } \\
\text { cropping pattern }\end{array}$ & 3.50 & 1.18 & 2.31 & 1.32 & 2.36 & 1.28 & 3.00 & 1.29 & 3.00 & 1.37 & 3.40 & 1.82 \\
\hline $\begin{array}{l}\text { Does not satisfy } \\
\text { my preference }\end{array}$ & 2.90 & 1.20 & 2.23 & 1.17 & 2.57 & 1.45 & 3.54 & 1.66 & 3.00 & 1.37 & 3.20 & 1.79 \\
\hline Bad quality & 3.10 & 1.20 & 2.54 & 1.51 & 2.14 & 1.17 & 3.38 & 1.39 & 2.59 & 1.00 & 3.20 & 1.30 \\
\hline $\begin{array}{l}\text { Not needed any } \\
\text { longer-outdated }\end{array}$ & 3.10 & 0.88 & 2.46 & 1.27 & 2.21 & 1.19 & 2.92 & 1.50 & 2.35 & 1.22 & 3.20 & 1.30 \\
\hline $\begin{array}{c}\text { Replaced by } \\
\text { different } \\
\text { technology }\end{array}$ & 4.00 & 0.94 & 2.15 & 0.90 & 2.14 & 1.35 & 3.46 & 1.61 & 2.47 & 1.07 & 3.20 & 1.30 \\
\hline Lodging & 3.00 & 1.25 & 1.92 & 0.76 & 2.21 & 1.25 & 2.54 & 1.20 & 2.41 & 0.94 & 2.80 & 1.10 \\
\hline $\begin{array}{l}\text { No market for the } \\
\text { variety }\end{array}$ & 2.90 & 1.10 & 2.38 & 1.19 & 1.93 & 0.83 & 2.00 & 0.91 & 2.18 & 0.95 & 2.40 & 1.34 \\
\hline $\begin{array}{l}\text { Time constraints } \\
\text { (too busy) }\end{array}$ & 3.00 & 1.05 & 2.92 & 1.55 & 2.79 & 1.53 & 3.77 & 1.69 & 3.18 & 1.51 & 3.40 & 1.52 \\
\hline $\begin{array}{c}\text { Damage (pest, } \\
\text { drought) }\end{array}$ & 2.90 & 1.45 & 2.31 & 1.32 & 2.29 & 1.14 & 3.08 & 1.89 & 2.35 & 1.00 & 2.60 & 1.14 \\
\hline $\begin{array}{l}\text { Too difficult to } \\
\text { apply }\end{array}$ & 3.20 & 1.14 & 2.92 & 1.50 & 2.50 & 1.22 & 3.15 & 1.82 & 3.00 & 1.27 & 2.60 & 1.34 \\
\hline Too expensive & 2.60 & 1.07 & 1.92 & 0.64 & 2.43 & 1.50 & 2.46 & 1.56 & 2.76 & 1.44 & 3.00 & 1.58 \\
\hline Labor shortage & 2.40 & 0.97 & 2.23 & 1.30 & 2.64 & 1.60 & 3.08 & 1.89 & 3.06 & 1.43 & 2.80 & 1.30 \\
\hline $\begin{array}{c}\text { Labor costs are } \\
\text { too high } \\
\text { Weather }\end{array}$ & 2.20 & 0.79 & 2.08 & 1.19 & 2.36 & 1.22 & 3.00 & 1.87 & 2.53 & 1.42 & 2.40 & 0.89 \\
\hline $\begin{array}{l}\text { conditions did not } \\
\text { allow use }\end{array}$ & 2.30 & 0.67 & 2.00 & 1.00 & 2.29 & 1.07 & 2.69 & 1.18 & 2.35 & 0.93 & 2.60 & 0.89 \\
\hline $\begin{array}{l}\text { Technology is not } \\
\text { available }\end{array}$ & 2.80 & 1.23 & 2.00 & 1.00 & 2.64 & 1.15 & 2.54 & 1.20 & 2.41 & 0.71 & 3.20 & 1.30 \\
\hline $\begin{array}{l}\text { Technology is not } \\
\text { suitable for my } \\
\text { field conditions }\end{array}$ & 3.10 & 1.37 & 2.46 & 1.56 & 2.07 & 1.00 & 3.31 & 1.80 & 2.59 & 1.42 & 3.80 & 1.48 \\
\hline Plants died & 1.70 & 0.67 & 2.46 & 1.56 & 1.79 & 0.58 & 1.77 & 1.09 & 1.94 & 0.56 & 3.50 & 1.18 \\
\hline
\end{tabular}

Note: Likert-scale rating of 1 (strongly disagree) to 6 (strongly agree).

Most farmers who were introduced to AWD adopted the technology (80.6\%) and of those half (55.2\%) were still practicing AWD at the time of the survey. Farmers who discontinued applying AWD expressed that 'it was too difficult to apply' and 'time constraints' as the main barriers (Table 4). The use of a combine harvester was adopted by $53 \%$ of the farmers who were introduced to that technology with $22 \%$ of those farmers still using the technology in 2018. The reasons for not continuing the use of combine harvester were that farmers had 'time constraints', 'combine harvester were not available' and that there was a 'labor shortage'. Half (51\%) of the farmers who were introduced to mechanical transplanter initially adopted that technology. However, none of the farmers were still using mechanical transplanter in 2018. Farmers rated 'time constraints', 'labor shortage', and 'does not fit cropping pattern' as the barriers to adoption. Furthermore, $54 \%$ of the farmers who were introduced to drum seeder machines reported to have adopted their use. However, only one farmer was using a drum seeder in 2018. The barriers to adopting the drum seeder included 'did not satisfy preferences', 'low yield' and that the drum seeder was 'replaced by different technology'. The IRRI superbag was adopted by $46 \%$ of the farmers who were introduced to the IRRI superbag. Only one farmer was still using the superbag with the others referring to the 'unsuitability of the superbag to their field condition', 'their plants have died' and it 'did not fit their cropping pattern'.

\subsection{Income Allocation}

Participants were asked to indicate which type of income they use for their everyday expenditures but also for more special goods, home improvements and services such as education fees, transportation or health care. Results are presented in Figure 2 Farmers generally use their income which comes from rice production for rice which they consume. Furthermore, they use this type of income to afford inputs such as fertilizer and pesticides for their rice production, machine rental and machine purchase. Daily expenditures such as food, fruit and vegetables, water, and electricity are mainly sourced through their non-rice 
income. Furthermore, school and university fees, home improvements and other non-daily and non-essential expenditures are sourced from non-rice income.
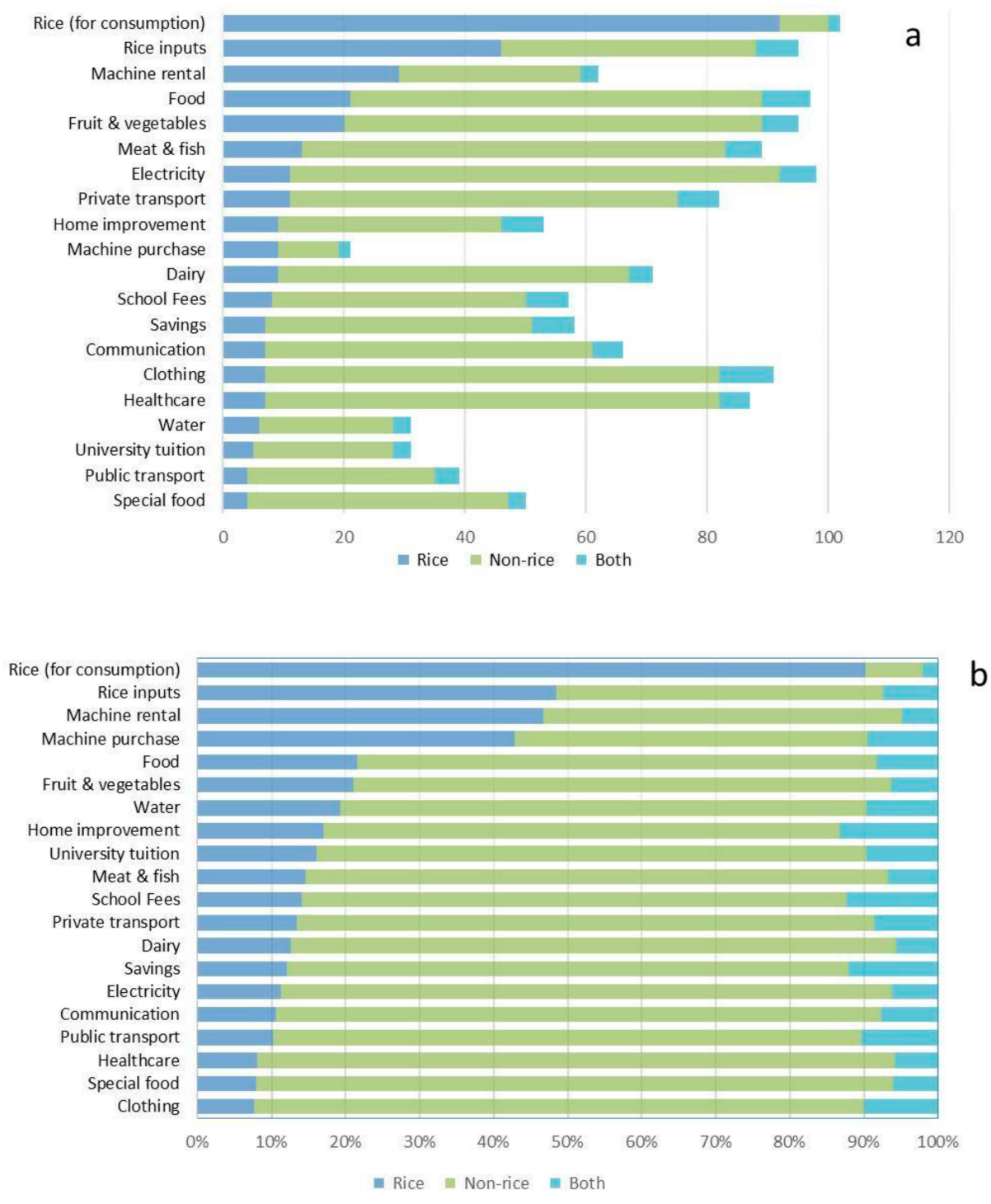

Figure 2. Income allocation by (a) number of farmers and (b) by percent of total income.

Farmers were asked whether they think that they had added revenue in rice farming since they have been using the best management practices. In total, $103(67 \%)$ farmers perceived a change in income. However only $48.4 \%(n=74)$ had an actual net change in income of US\$105.54 (SD = 174.40) in the DS, US\$121.07 (SD = 213.47) in WS1, and US\$122.22 (SD = 279.50) in WS2 (Table 2). Farmers were further asked whether they could remember what they used the extra income for. Results show that most of the farmers used it for food in general, to buy meat and fish, and fruits and vegetables. Furthermore, farmers also used that additional income for rice inputs and machine rental for rice production (Table 5).

\subsection{Perception of Change Due to the Adoption of Best Management Practices}

Farmers rated different dimensions of change. Results show that farmers perceived greatest changes in social capital (Table 6), followed by human capital, and poverty reduction. Farmers perceived least changes in land tenure and physical capital. 
Table 5. Distribution of farmers who have a recollection of where they allocated their added income from rice, and percentage of income allocated by expenditure item $(n=39)$.

\begin{tabular}{|c|c|c|c|c|}
\hline Expenditure & $n$ & $\% n$ & $\%$ Allocated & IQR \\
\hline Food & 21 & 53.8 & 30 & 35 \\
\hline Meat and fish & 14 & 35.9 & 20 & 14 \\
\hline Fruit and vegetables & 15 & 38.5 & 20 & 8 \\
\hline Dairy & 8 & 20.5 & 5 & 11 \\
\hline Rice (for consumption) & 5 & 12.8 & 100 & 23 \\
\hline Special food & 2 & 5.1 & 5 & 0 \\
\hline Healthcare & 5 & 12.8 & 10 & 0 \\
\hline Clothing & 7 & 17.9 & 10 & 3 \\
\hline Communication & 2 & 5.1 & 25 & 25 \\
\hline School Fees & 7 & 17.9 & 30 & 23 \\
\hline University tuition & 3 & 7.7 & 25 & 20 \\
\hline Private transport & 6 & 15.4 & 12.5 & 31 \\
\hline Public transport & 1 & 2.6 & 5 & 0 \\
\hline Rice inputs & 22 & 56.4 & 35 & 43 \\
\hline Electricity (home utility) & 6 & 15.4 & 10 & 0 \\
\hline Machine rental for rice production & 11 & 28.2 & 15 & 22 \\
\hline Machine purchase for rice production & 3 & 7.7 & 10 & 8 \\
\hline Savings & 7 & 17.9 & 32.5 & 30 \\
\hline Home improvement & 5 & 12.8 & 7.5 & 5 \\
\hline
\end{tabular}

Note: multiple responses; \%allotted—median of rice income percentage; IQR—inter-quartile range.

Table 6. Reliability, means, and standard deviations of farmers' perception of changes due to the adoption of best management practices.

\begin{tabular}{|c|c|c|c|c|c|}
\hline & $\begin{array}{c}\text { Description } \\
\text { (All Items Concern Farmers' Perceptions) }\end{array}$ & $\begin{array}{l}\text { Number of } \\
\text { Items }\end{array}$ & Cronbach's $\alpha$ & Mean & SD \\
\hline Financial capital & Access and use of financial support & 3 & 0.535 & 2.49 & 0.94 \\
\hline Employment & $\begin{array}{l}\text { Uptake of additional employment by family } \\
\text { members, increased on farm employment } \\
\text { opportunities }\end{array}$ & 3 & 0.640 & 2.70 & 1.07 \\
\hline $\begin{array}{l}\text { Agricultural } \\
\text { production }\end{array}$ & $\begin{array}{l}\text { Yield change, perception of production } \\
\text { changes and changes in workload }\end{array}$ & 6 & 0.643 & 3.23 & 0.54 \\
\hline Physical capital & $\begin{array}{l}\text { Ability to purchase farming equipment (e.g., } \\
\text { machineries) }\end{array}$ & 5 & 0.913 & 2.02 & 1.03 \\
\hline Poverty & Ability to spend money & 3 & 0.491 & 3.66 & 0.76 \\
\hline Land tenure & Ability purches more farming land & 4 & 0.839 & 1.70 & 0.74 \\
\hline Social capital & Ability to disseminate the knowledge gained & 3 & 0.861 & 4.16 & 1.00 \\
\hline Human capital & Ability to apply new knowledge & 4 & 0.797 & 3.91 & 0.91 \\
\hline Natural capital & $\begin{array}{l}\text { Increase in biodiversity (flora and fauna) } \\
\text { Ability to eat more food, to eat more }\end{array}$ & 4 & 0.617 & 2.46 & 0.82 \\
\hline Food security & $\begin{array}{l}\text { frequently, to eat a greater diversity of food } \\
\text { products }\end{array}$ & 8 & 0.892 & 2.90 & 0.88 \\
\hline Cultural capital & Changes in cultural habits & 6 & 0.881 & 2.74 & 1.07 \\
\hline Health & Increase in health outcomes & 3 & 0.674 & 2.67 & 0.98 \\
\hline
\end{tabular}

Note. $n=153$, items for each indicator came from [30].

\section{Discussion}

The adoption of sustainable rice farming technologies is an important contribution to climate change adaptation and mitigation. The present study went beyond a conventional adoption study e.g., $[18,19,23]$ by looking at subsequent adoption effects on additional revenue allocation and farmers' perception of social, economic and environmental change. As such it contributes to this Special Issue on "Farmers' Adoption of Agricultural Innovations and their Impact".

Results of the present study show that almost all participating farmers adopted the new high-yielding rice varieties. This is not surprising as Yogyakarta is one of the regions 
in Indonesia with the highest yield gaps [31]. Therefore, this area had great potential to increase yields through improvement of crop-management practices and the introduction of new varieties. The CORIGAP project introduced a variety of technologies and practices determined by prior needs assessment. The number of farmers who reported to have been introduced to the different practices and technologies varies considerably. Throughout the project phase, several trainings and field trials were conducted and farmers were free to take part in these activities. Farmers for the present study were selected based on their location and not their participation or otherwise in previous trainings. It needs to be noted that the current sample was drawn purposively from a list of project farmers who adopted at least one technology or practice and does not represent a complete random sample as it excludes the farmers who did not adopt technologies. However, farmers' demographic characteristics are comparable with other studies [6]. The present sample was slightly older and consisted of more female farmers that Rondhi's [6], which used data from 87,3330 rice farming households.

At least $50 \%$ of those farmers who were familiar with CORIGAP-promoted technologies and practices reported that they were adopters. Highest adoption was reported for new varieties, AWD, and drum seeder. However, by 2018 combine harvesters, mechanical transplanters and drum seeders had largely been abandoned. Farmers reported that time constraints and labor shortages were the main reasons for not using combine harvesters and mechanical transplanter anymore. Furthermore, participants also mentioned that combine harvesters were not available. These machines are very expensive and are usually not bought by a single farmer or even a farming community, therefore, service providers need to be available for farmers to rent the machines. This emphasizes the need for business model development around service providers [32]. With regard to mechanical transplanters, farmers also acknowledged that they do not fit their cropping pattern and are, therefore, unsuitable.

Glover et al. (2019) [33] highlight the need to better understand better the dynamic processes of experimentation and learning that underlie technological change. Farmers' decisions to adopt, adapt, disadopt, or re-adopt agricultural innovations is only part-determined by the innovations in question; often of greater importance are farmers' aspirations and management skills that, in turn, need to be supported by an enabling environment [34,35]. As Glover et al. (2016) [36] write "technology is something people do, make or remake, not something they receive or adopt". The authors recognize shortfalls in their study but it does shed light on the processes behind some of the intermediate development outcomes arising from farmer adoption.

Almost all farmers ( $>90 \%$ ) said that they were still using the improved rice varieties. These varieties have contributed to a reduction in the yield gap [37]. Furthermore, half of the farmers who reported having adopted AWD were still using it at the time of the survey. Farmers who had abandoned AWD said that it was too difficult to apply and they were facing time constraints. This finding is in line with other studies that found that farmers adopt practices and technologies which are easy for them to apply $[18,30]$. Other studies have shown that demonstrations and field trials can be helpful in the dissemination and adoption of complex practices such as AWD $[13,18]$. Knowledge dissemination and acquisition will be required to influence changes. Through project activities, farmers gained knowledge through official sources such as the International Rice Research Institute and governmental extension services to ensure the discourse between innovators and end users, which has been described to be favorable for adoption [38].

Results show that farmers perceive changes in social and human capital indicating that they acquired knowledge which they are also able to propagate among their peers. Social capital has been shown to be an important factor in understanding farmers' behavior towards adoption and technologies [39,40]. Farmers' perception of a positive change in natural capital was rather low. However, it needs to be noted that the introduced technologies and practices did not directly influence natural capital, and that CORIGAP has not developed natural capital indicators reflecting biodiversity etc. 
On average, farmers adopted two technologies, and 26\% $(n=40)$ of the participants adopted more than two technologies which may show that a single innovation may not precipitate a perception of change. Furthermore, most farmers $(78 \%)$ reported that they perceived a change in income due to the adoption of more than one technology or practice. However, only $49 \%$ of the participants had an actual income increase. Economic benefits from technology adoption have been described in many studies and, in addition to the actual income increase, farmers of the present study also perceived a reduction in poverty aspects. Farmers reported that they have more money in general and that they are able to spend this money. We controlled for their general expenditures separated for rice and non-rice income. Results show that farmers use their income from rice mainly for rice farming activities such as buying inputs or covering machine rental. Furthermore, rice for consumption is also paid for by their rice income. Farmers who could remember what they spend their additional income on were using this income also for rice inputs and machine rental. Farmers also used the extra income to buy meat, vegetables and fruits. This shows that farmers invest in their farming activities to potentially expand and improve their practices but also invest in their own health and nutrition by using the additional income to source food. Similar results have been shown in a qualitative assessment of income allocation in Myanmar [27].

Farmers' decision to allocate extra income to secure their future and providing nutritious food is important. CORIGAP activities have shown a positive effect on the first two SDGs 'No Poverty' and 'Zero Hunger'. However, it is important to note that this exploratory study has some limitations. The sampling process was a convenient sample based on farmer location; farmers (adopters) were not randomly sampled. Furthermore, the sample size is rather small to draw overarching conclusions. Our study, however, provides important insights on method development and long term adoption, outcomes, output and consequently impacts.

Looking ahead, much still needs to be done to foster agricultural development. Many adoption studies are still largely a snapshot of a situation that report adoption as a binary outcome [41] and seldom address whether adoption continues over several years and/or the intensity of the adoption i.e., the percentage of land area that a farmer uses for the agricultural innovation [36]. Furthermore, a key challenge is the scaling out of these technologies to greater numbers of farmers and scaling up in terms of fostering the organizational, governance and policy environments that encourage scaling [42]. Furthermore, this scaling has to enhance social equity and foster improved livelihood trajectories, including off-farm ones.

\section{Conclusions}

The results of the present study demonstrated that farmers adopted CSA, especially improved varieties and AWD. However, some farmers indicated that they had difficulties applying CSA especially machinery, which was difficult to source. Farmers invested their additional income into farming business and improved diets. Farmers perceived a significant change in social and human capital indicating knowledge acquisition and dissemination of CSA. In addition farmers also perceived a reduction in poverty levels due to the adoption of CSA. The overall perception of change was determined by the number of CSA technologies and practices adopted. The present study highlights the links between on- farm development outputs, outcomes and impact, and provides a case study for the evolution of climate-resilient farming systems.

Supplementary Materials: The following are available online at https://www.mdpi.com/article/ 10.3390/agronomy11050881/s1, Table S1: Number of farmers allocating fresh paddy produced to different use, Table S2: Farmers' Likert-scale rating on reasons to discontinue use of BMP technology, Yogyakarta Indonesia.

Author Contributions: Conceptualization, M.C., A.H.d.G. and J.H.; methodology, M.C., A.H.d.G., A.B.P., S. and M.K.; software, A.H.d.G. and M.C.; validation, A.H.d.G., A.B.P., S. and M.K.; formal 
analysis, M.C. and A.H.d.G.; investigation, M.C. and A.B.P.; resources, A.B.P., S. and M.K.; data curation, A.H.d.G., A.B.P., S. and M.K.; writing-original draft preparation, M.C. and J.H.; writingreview and editing, M.C., A.H.d.G. and J.H.; visualization, M.C., A.H.d.G. and J.H.; supervision, M.C.; project administration, M.C. All authors have read and agreed to the published version of the manuscript.

Funding: This research was funded by Swiss Agency for Development and Cooperation (SDC), grant number 81016734 .

Institutional Review Board Statement: The study was conducted according to the Declaration of Helsinki. At the time of the study no ethics board was available but the questionnaire and sampling was approved by the IRRI research Ethics committee for the Chinese context (2019-003-A-2016-61) and Vietnamese context (2019-0006-A-2016-61).

Informed Consent Statement: Informed consent was obtained from all participants involved in the study.

Data Availability Statement: The data presented in this study is available on request from the corresponding author.

Acknowledgments: We would like to acknowledge the enumerators from Yogyakarta Assessment Institute of Agricultural Technology for collecting the data. Helena Wehmeyer for providing the map, Grant Singleton and Ing. Martin Gummert for supporting these studies under CORIGAP.

Conflicts of Interest: The authors declare no conflict of interest.

\section{References}

1. Campbell, B.M.; Hansen, J.; Rioux, J.; Stirling, C.M.; Twomlow, S.; Wollenberg, E. Urgent action to combat climate change and its impacts (SDG 13): Transforming agriculture and food systems. Curr. Opin. Environ. Sustain. 2018, 34, 13-20. [CrossRef]

2. Chandra, A.; McNamara, K.E.; Dargusch, P. Climate-smart agriculture: Perspectives and framings. Clim. Policy 2018, 18, 526-541. [CrossRef]

3. Partey, S.T.; Zougmoré, R.B.; Ouédraogo, M.; Campbell, B.M. Developing climate-smart agriculture to face climate variability in West Africa: Challenges and lessons learnt. J. Clean. Prod. 2018, 187, 285-295. [CrossRef]

4. Indonesia, S. Statistical Yearbook of Indonesia 2017; Statistics Indonesia: Jakarta, Indonesia, 2017.

5. $\quad$ GRiSP. Rice Almanac, 4th ed.; International Rice Research Institute: Los Baños, Philippines, 2013; p. 283.

6. Rondhi, M.; Khasan, A.F.; Mori, Y.; Kondo, T. Assessing the Role of the Perceived Impact of Climate Change on National Adaptation Policy: The Case of Rice Farming in Indonesia. Land 2019, 8, 81. [CrossRef]

7. Ministry of Agriculture. Agricultural Statistics; Susanti, A.A., Waryanto, B., Eds.; Center for Agricultural Data and Information System (Ministry of Agriculture): Jakarta, Indonesia, 2018.

8. Boer, R. The threat of global climate change on Indonesia's food security. Agromedia 2011, 15, 16-20.

9. Dewi, E.R.; Whitebread, A.M. Use of climate forecast information to manage lowland rice-based cropping systems in Jakenan, Central Java, indonesia. Asian J. Agric. Res. 2017, 11, 66-77. [CrossRef]

10. Sembiring, H.; Subekti, N.A.; Erythrina, N.D.; Priatmojo, B.; Stuart, A.M. Yield Gap Management under Seawater Intrusion Areas of Indonesia to Improve Rice Productivity and Resilience to Climate Change. Agriculture 2020, 10, 1. [CrossRef]

11. Lakitan, B.; Hadi, B.; Herlinda, S.; Siaga, E.; Widuri, L.I.; Kartika, K.; Lindiana, L.; Yunindyawati, Y.; Meihana, M. Recognizing farmers' practices and constraints for intensifying rice production at Riparian Wetlands in Indonesia. NJAS-Wagening. J. Life Sci. 2018, 85, 10-20. [CrossRef]

12. FAO. Climate-Smart Agriculture Sourcebook; Food and Agriculture Organization of the United Nations: Rome, Italy, 2013.

13. Lampayan, R.M.; Rejesus, R.M.; Singleton, G.R.; Bouman, B.A. Adoption and economics of alternate wetting and drying water management for irrigated lowland rice. Field Crop. Res. 2015, 170, 95-108. [CrossRef]

14. Sander, B.O.; Wassmann, R.; Siopongco, J.D.L.C. Mitigating Greenhouse Gas Emissions from Rice Production through WaterSaving Techniques: Potential, Adoption and Empirical Evidence. In Climate Change and Agricultural Water Management in Developing Countries; Hoanh, C.T., Johnston, R., Smakhtin, V., Eds.; CABI Publishing: Wallingford, UK, 2016 ; pp. $193-207$.

15. Minh, T.T.; Friederichsen, R.; Neef, A.; Hoffmann, V. Niche action and system harmonization for institutional change: Prospects for demand-driven agricultural extension in Vietnam. J. Rural Stud. 2014, 36, 273-284. [CrossRef]

16. Klerkx, L.; Leeuwis, C. Matching demand and supply in the agricultural knowledge infrastructure: Experiences with innovation intermediaries. Food Policy 2008, 33, 260-276. [CrossRef]

17. Pamuk, H.; Bulte, E.H.; Adekunle, A.A. Do decentralized innovation systems promote agricultural technology adoption? Experimental evidence from Africa. Food Policy 2014, 44, 227-236. [CrossRef]

18. Connor, M.; Tuan, L.A.; DeGuia, A.H.; Wehmeyer, H. Sustainable rice production in the Mekong River Delta: Factors influencing farmers' adoption of the integrated technology package “One Must Do, Five Reductions" (1M5R). Outlook Agric. 2021, 50 [CrossRef] 
19. Dai, X.; Chen, J.; Chen, D.; Han, Y. Factors affecting adoption of agricultural water-saving technologies in Heilongjiang Province, China. Water Policy 2015, 17, 581-594. [CrossRef]

20. Joffre, O.M.; Poortvliet, P.M.; Klerkx, L. To cluster or not to cluster farmers? Influences on network interactions, risk perceptions, and adoption of aquaculture practices. Agric. Syst. 2019, 173, 151-160. [CrossRef]

21. Ali, A.; Rahut, D.B. Impact of Agricultural Extension Services on Technology Adoption and Crops Yield: Empirical Evidence from Pakistan. Asian J. Agric. Rural Dev. 2013, 11, 801-812.

22. Dang, H.L.; Li, E.; Nuberg, I.; Bruwer, J. Farmers' assessments of private adaptive measures to climate change and influential factors: A study in the Mekong Delta. Vietnam. Nat. Hazards 2014, 71, 385-401. [CrossRef]

23. Bopp, C.; Engler, A.; Poortvliet, P.M.; Jara-Rojas, R. The role of farmers' intrinsic motivation in the effectiveness of policy incentives to promote sustainable agricultural practices. J. Environ. Manag. 2019, 244, 320-327. [CrossRef] [PubMed]

24. Dilling, L.; Prakash, A.; Zommers, Z.; Ahmad, F.; Singh, N.; De Wit, S.; Nalau, J.; Daly, M.; Bowman, K. Is adaptation success a flawed concept? Nat. Clim. Chang. 2019, 9, 572-574. [CrossRef]

25. Eriksen, S.; Schipper, E.L.F.; Scoville-Simonds, M.; Vincent, K.; Adam, H.N.; Brooks, N.; Harding, B.; Khatri, D.; Lenaerts, L.; Liverman, D.; et al. Adaptation interventions and their effect on vulnerability in developing countries: Help, hindrance or irrelevance? World Dev. 2021, 141, 105383. [CrossRef]

26. Schipper, E.; Eriksen, S.; Carril, L.F.; Glavovic, B.; Shawoo, Z. Turbulent transformation: Abrupt societal disruption and climate resilient development. Clim. Dev. 2020, 1-8. [CrossRef]

27. Connor, M.; San, S.S. Sustainable rice farming and its impact on rural women in Myanmar. Dev. Pract. 2020, 31, 1-10. [CrossRef]

28. Connor, M.; San, S.S. Sustainable rice production in Myanmar impacts and food security and livelihood changes. J. Agric. Sustain. 2020, 31, 49-58.

29. Lambrecht, I.; Vanlauwe, B.; Merckx, R.; Maertens, M. Understanding the Process of Agricultural Technology Adoption: Mineral Fertilizer in Eastern DR Congo. World Dev. 2014, 59, 132-146. [CrossRef]

30. Wehmeyer, H.; De Guia, A.H.; Connor, M. Reduction of Fertilizer Use in South China-Impacts and Implications on Smallholder Rice Farmers. Sustainability 2020, 12, 2240. [CrossRef]

31. Stuart, A.M.; Pame, A.R.P.; Silva, J.V.; Dikitanan, R.C.; Rutsaert, P.; Malabayabas, A.J.B.; Lampayan, R.M.; Radanielson, A.M.; Singleton, G.R. Yield gaps in rice-based farming systems: Insights from local studies and prospects for future analysis. Field Crop. Res. 2016, 194, 43-56. [CrossRef]

32. Van Loon, J.; Woltering, L.; Krupnik, T.J.; Baudron, F.; Boa, M.; Govaerts, B. Scaling agricultural mechanization services in smallholder farming systems: Case studies from sub-Saharan Africa, South Asia, and Latin America. Agric. Syst. 2020, 180, 102792. [CrossRef]

33. Glover, D.; Sumberg, J.; Ton, G.; Andersson, J.; Badstue, L. Rethinking technological change in smallholder agriculture. Outlook Agric. 2019, 48, 169-180. [CrossRef]

34. Hellin, J.; Ridaura, S.L. Soil and water conservation on Central American hillsides: If more technologies is the answer, what is the question? Aims Agric. Food 2016, 1, 194-207. [CrossRef]

35. Sumberg, J. Constraints to the Adoption of Agricultural Innovations: Is it Time for a Re-Think? Outlook Agric. 2005, 34, 7-10. [CrossRef]

36. Glover, D.; Sumberg, J.; Andersson, J.A. The Adoption Problem; or Why We Still Understand so Little about Technological Change in African Agriculture. Outlook Agric. 2016, 45, 3-6. [CrossRef]

37. Parhusip, D.; Manurung, E.D.; Girsang, S.S. Reduction of rice yield gap by fertilizer and new varieties in North Sumatera. In IOP Conference Series: Earth and Environmental Science; IOP Publishing: Bristol, UK, 2020; Volume 484, p. 012061.

38. Klerkx, L.; Aarts, N. The interaction of multiple champions in orchestrating innovation networks: Conflicts and complementarities. Technovation 2013, 33, 193-210. [CrossRef]

39. Hunecke, C.; Engler, A.; Jara-Rojas, R.; Poortvliet, P.M. Understanding the role of social capital in adoption decisions: An application to irrigation technology. Agric. Syst. 2017, 153, 221-231. [CrossRef]

40. Van Rijn, F.; Bulte, E.; Adekunle, A. Social capital and agricultural innovation in Sub-Saharan Africa. Agric. Syst. 2012, 108, 112-122. [CrossRef]

41. Sumberg, J. Opinion: The effects of technology adoption on food security: Linking methods, concepts and data. Food Secur. 2016, 8, 1037-1038. [CrossRef]

42. Woltering, L.; Fehlenberg, K.; Gerard, B.; Ubels, J.; Cooley, L. Scaling—from "reaching many" to sustainable systems change at scale: A critical shift in mindset. Agric. Syst. 2019, 176, 102652. [CrossRef] 